\title{
Occurrence of Giardia intestinalis in dairy goats and evaluation of risk factors for infection: research note
}

\author{
Ocorrência de Giardia intestinalis em caprinos destinados à produção \\ leiteira e avaliação de fatores de risco para a infecção: nota de pesquisa
}

Adriana Pittella Sudré, ${ }^{* a}$ Melissa Carvalho Machado do Couto, ${ }^{*}$ Teresa Cristina Bergamo do Bomfim*

\begin{abstract}
The aim of this study was to establish the occurrence of Giardia intestinalis in goat fecal samples from two dairy farms (A and B) located in Rio de Janeiro state, Brazil, assessing possible risk factors for infection. Fecal samples from all young animals (up to one year of age) $(n=58)$ and from $10 \%$ of adult animals $(n=18)$ were collected. Samples were collected directly from the rectum and were submitted to centrifuge-flotation in sugar saturate solution for microscopic search of Giardia cysts. From 76 analyzed samples, $17(22.4 \%)$ were positive for Giardia cysts. All positive samples came from young animals of farm A. Also, dog fecal samples $(n=9)$ were collected to evaluate their role in parasite transmission. Three dog samples $(33.3 \%)$ were positive for Giardia cysts. Presence of helminth eggs was only observed in animals from farm A. Eimeria sp. oocysts were observed in fecal samples from both farms. The comparison of hygienic-sanitary and management conditions of both farms indicated that the high rate of infection in young animals from farm $A$ was due to an association of risk factors: intensive raising of young animals in installations made of wooden slats floor, fecal accumulation underneath it, and the presence of domestic animals inside goat installations. The high Giardia positivity and the observation of risk factors for transmission call attention to the importance of effective prophylactic measures and patterns of management.
\end{abstract}

Keywords: dairy goat, Giardia, risk factors.

\section{Resumo}

Este estudo teve como objetivo estabelecer a ocorrência de Giardia intestinalis em amostras fecais de caprinos, provenientes de duas caprinoculturas (A e B) localizadas no estado do Rio de Janeiro, Brasil, avaliando possíveis fatores de risco para a infecção. Foram coletadas amostras fecais de todos os animais jovens (até um ano de idade) ( $n=58)$ e de $10 \%$ dos animais adultos ( $n=18$ ). As amostras foram coletadas diretamente do reto e submetidas à técnica de centrífugo-flutuação em solução saturada de açúcar para pesquisa de cistos de Giardia por microscopia. Das 76 amostras analisadas, 17 (22,4\%) foram positivas para cistos de Giardia, sendo todas provenientes de animais jovens da caprinocultura A. Também foram coletadas amostras de fezes caninas $(n=9)$ da propriedade A, para avaliação do papel destes no ciclo de transmissão. Três $(33,3 \%)$ amostras caninas foram positivas para cistos de Giardia. A presença de ovos de helmintos foi apenas observada em animais da propriedade A. Ambas as propriedades apresentaram positividade para oocistos de Eimeria sp. A comparação das condições higiênico-sanitárias e de manejo de ambas as caprinoculturas indicou que a alta taxa de infecção em animais jovens da caprinocultura A ocorreu por uma associação de fatores de risco: criação intensiva, instalações de piso de madeira ripada, acúmulo de fezes abaixo das instalações e a presença de animais domésticos no interior das instalações dos caprinos. A alta positividade para Giardia e a observação de fatores de risco para a transmissão chamam a atenção para a importância de medidas profiláticas e padrões de manejo eficazes.

Palavras-chave: caprino, produção leiteira, Giardia, fatores de risco.

\section{Introduction}

Gastrointestinal protozoa of the genus Giardia are responsible for considerable economic losses in livestock associated with morbidity and mortality (Aloisio et al., 2006; Geurden et al., 2010;
Sweeny et al., 2011). Giardia intestinalis infection in goats can be asymptomatic or associated with severe diarrhea and, depending on nutritional status, management, and concomitant presence of other pathogens, lead to animal death (Koudela and Vitovec 1998; Geurden et al., 2010).

\footnotetext{
* Universidade Federal Rural do Rio de Janeiro - CPGCV - Departamento de Parasitologia Animal - Instituto de Veterinária - BR 465, km 7, Seropédica Rio de Janeiro - Brazil - 23890-000.

a Present address: Universidade Federal Fluminense - Instituto Biomédico - Departamento de Microbiologia e Parasitologia - Rua Professor Ernani Melo, 101/ Sala 212-D - São Domingos, Niterói - Rio de Janeiro - Brazil - 24210-130.

Corresponding author: Teresa Cristina Bergamo do Bomfim - Universidade Federal Rural do Rio de Janeiro - CPGCV - Departamento de Parasitologia Animal - Instituto de Veterinária - BR 465, km 7, Seropédica - Rio de Janeiro - Brazil - 23890-000. Email: tcbb@ufrrj.br - Tel/Fax: 55-21-26821617
} 
The transmission of this protozoa occurs most often through ingestion of cysts in contaminated water and food (Smith et al., 2007; Robertson, 2009). Several risk factors have been associated with Giardia intestinalis transmission in goats, such as age, housing of animals without separation of age groups, agglomeration, humidity, type and quality of food, hygienicsanitary conditions, and construction of installations inadequate for the type of animal production (Bomfim et al., 2005; Geurden et al., 2010).

The role of goats in zoonotic transmission of Giardia intestinalis has been extensively discussed in literature, especially the prevalence of infection in this host and the potential for environmental contamination (Smith et al., 2007; Robertson, 2009; Geurden et al., 2010; Feng and Xiao, 2011). However, fewer studies regarding Giardia prevalence in goats were performed worldwide (Díaz et al., 1996; Castro-Hermida et al., 2005a; Castro-Hermida et al., 2005b; Bomfim et al., 2005; Van der Giessen et al., 2006; Castro-Hermida et al., 2007a; CastroHermida et al., 2007b; Gueurden et al., 2008; Ruiz et al., 2008; Sprong et al., 2009; Berrilli et al., 2012), with only one study in Brazil (Bomfim et al., 2005).

Thus, the aim of this study was to establish the occurrence of Giardia intestinalis in two dairy goat farms located in Rio de Janeiro state, Brazil, verifying the association of possible risk factors for the infection.

\section{Material and methods}

The study was performed in two dairy goat farms located in Niterói municipality, Rio de Janeiro state, Brazil, which were named $A$ and $B$. The farms were chosen based on convenience of location and availability to participate in the study. Up to three visits to each farm were performed from November 2009 to June 2010.

A questionnaire was used to characterize the two farms. The aim of this questionnaire was to obtain information about installations, management, and hygienic-sanitary conditions of the animals to assess risk factors. The information were obtained through owner/responsible interview and observations made during the visit.

Housing for the animals in both farms was built of masonry or wood. Hygienic conditions of the farms were classified according to the following criteria: good (good sanitation); satisfactory (satisfactory sanitation); average (few accumulation of feces, food remains, and humidity) and unsatisfactory (considerable accumulation of feces, food remains, and humidity).

Goat fecal samples were collected directly from the rectum of all animals up to one year of age, and of $10 \%$ of animals with more than one year of age.

Additionally, because dogs were observed inside goat installations in farm $A$, nine canine fresh fecal samples were collected from the soil in order to evaluate their potential for parasite transmission. To avoid cross contamination, only the superficial part of the samples that were not in contact with the soil were collected. All fecal samples were stored under refrigeration until processing.

Fecal samples were processed according to Huber et al (2007). Briefly, samples were homogenized with distilled water and filtered through disposable sieves with a gauze overlay.
The filtered material was placed inside two $15 \mathrm{~mL}$ test tubes and centrifuged at $402.48 \mathrm{xg}$ for 10 minutes, after which the supernatant was discarded. One of the tubes was stored under refrigeration, and sugar saturated solution with specific density of $1.30 \mathrm{~g} / \mathrm{ml}$ was added to the sediment of the second tube. After homogenization the material was centrifuged at $402.48 \mathrm{xg}$ for 5 minutes. The tube was then toped up with sugar solution, covered with a slide coverslip and left at rest for 3 minutes. The coverslip was mounted on a glass slide and examined under an optic microscope with and without phase contrast.

\section{Results}

From a total of 76 fecal samples collected, 58 came from young animals (up to one year of age) and 18 came from adult female animals (> 1 year of age). Among the young animals, 43 were female and 15 were male. Microscopic analysis of fecal samples showed $29.31 \%$ (17/58) of young animals positive for Giardia intestinalis cysts. Adult goats were not diagnosed with Giardia.

A total of 42 fecal samples, 31 from young animals (23 female and 8 male) and 11 from adult animals, were collected at farm A. Microscopic analysis of fecal samples showed $100 \%$ animal infection for at least one parasite species. Poliparasitism occurred in $92.9 \%$ (39/42) of animals. Young goats were positive for Giardia intestinalis $(54,8 \%)$ in addition to other parasite species (Table 1). However, adult animals were not parasitized by Giardia even though other parasite species were diagnosed (Table 1).

A total of 34 fecal samples, 27 from young animals (20 female and 7 male) and 7 from adult animals, were collected at farm B. Microscopic analysis of samples did not reveal Giardia intestinalis parasitism in those animals, albeit some of the samples were positive for the genus Eimeria (Table 1). Finally, of the nine canine fecal samples collected from the soil of farm A, $3(33.3 \%)$ were positive for Giardia intestinalis cysts.

Both farms showed differences in management and hygienicsanitary conditions, which are compared in Table 2.

\section{Discussion}

The present study revealed a high rate of infection in young animals $(29.31 \%)$, which is even higher when only samples of young animals from farm $A$ are considered (54.8\%).

According to Robertson (2009), the prevalence of Giardia sp. in goats worldwide varies between 10 and $40 \%$. This variation is not only due to differences inherent to each region, but also to differences between studies, especially regarding animal age and type of diagnostic techniques employed.

In a study at the Canary Island, Ruiz et al. (2008) found positivity of $42.2 \%$ in 315 young animals through the association of three diagnostic techniques (microscopy, immunofluorescence and PCR). However, if only the microscopy results are considered, the positivity goes down to $26 \%$, emphasizing the need to combine techniques to achieve a more reliable diagnosis.

Thus, we believe that the use of only one diagnostic technique, coupled with the use of only one fecal sample from each animal, could have underestimated the real prevalence of this parasite in the studied region. Additionally, studies demonstrate that because of its easy transmission and high viability of cysts in the environment, when a longitudinal research of animals is made the prevalences could reach $100 \%$ (Koudela and Vitovec, 1998; Becher et al., 2001). 
Table 1: Absolute and relative frequencies of parasites diagnosed by microscopy through centrifuge-flotation in sugar solution technique of goat fecal samples from farms A and B.

\begin{tabular}{|c|c|c|c|c|c|c|c|c|}
\hline \multirow{3}{*}{$\begin{array}{l}\text { INTESTINAL } \\
\text { PARASITES }\end{array}$} & \multicolumn{4}{|c|}{ FARM A } & \multicolumn{4}{|c|}{ FARM B } \\
\hline & \multicolumn{2}{|c|}{$\begin{array}{c}\text { YOUNG GOATS } \\
\text { (UP TO } 1 \text { YEAR / N=31) }\end{array}$} & \multicolumn{2}{|c|}{$\begin{array}{l}\text { ADULT GOATS } \\
(>1 \text { YEAR / N=11) }\end{array}$} & \multicolumn{2}{|c|}{$\begin{array}{c}\text { YOUNG GOATS } \\
\text { (UP TO } 1 \text { YEAR / N=27) }\end{array}$} & \multicolumn{2}{|c|}{$\begin{array}{l}\text { ADULT GOATS } \\
(>1 \text { YEAR / N=7) }\end{array}$} \\
\hline & POSITIVE & NEGATIVE & POSITIVE & NEGATIVE & POSITIVE & NEGATIVE & POSITIVE & NEGATIVE \\
\hline G. intestinalis & $17(54.8 \%)$ & $14(45.2 \%)$ & 0 & $11(100 \%)$ & 0 & $27(100 \%)$ & 0 & $7(100 \%)$ \\
\hline Eimeria sp. & $30(96.8 \%)$ & $1(3.2 \%)$ & $11(100 \%)$ & 0 & $25(92.6 \%)$ & $2(7.4 \%)$ & $7(100 \%)$ & 0 \\
\hline Strongylid & $22(71 \%)$ & $9(29 \%)$ & $11(100 \%)$ & 0 & 0 & $27(100 \%)$ & 0 & $7(100 \%)$ \\
\hline Moniezia sp. & $2(6.5 \%)$ & 29 (93.5\%) & 0 & $11(100 \%)$ & 0 & $27(100 \%)$ & 0 & $7(100 \%)$ \\
\hline
\end{tabular}

Table 2: Comparison of major characteristics of management and hygienic-sanitary conditions observed between the two studied farms.

\begin{tabular}{|c|c|c|c|c|}
\hline \multirow[b]{2}{*}{ FARM CHARACTERISTICS } & \multicolumn{2}{|c|}{ FARM A } & \multicolumn{2}{|c|}{ FARM B } \\
\hline & YOUNG ANIMALS & ADULT ANIMALS & YOUNG ANIMALS & ADULT ANIMALS \\
\hline Type of Installations & $\begin{array}{l}\text { Suspended floor of } \\
\text { wooden slats }\end{array}$ & $\begin{array}{l}\text { Masonry floor not } \\
\text { suspended }\end{array}$ & $\begin{array}{l}\text { Suspended floor of } \\
\text { wooden slats }\end{array}$ & $\begin{array}{l}\text { Suspended floor of } \\
\text { wooden slats }\end{array}$ \\
\hline Hygiene conditions & unsatisfactory & unsatisfactory & unsatisfactory & unsatisfactory \\
\hline Raising system & Intensive & Semi-intensive & Intensive & Intensive \\
\hline Water origin & Nascent & Nascent & Artesian well & Artesian well \\
\hline $\begin{array}{l}\text { Presence of other animals } \\
\text { in installations }\end{array}$ & Yes & No & No & No \\
\hline $\begin{array}{c}\text { Presence of Giardia intestinalis } \\
\text { cysts }\end{array}$ & Yes & No & No & No \\
\hline
\end{tabular}

The results obtained in this study were very similar to those described by Bomfim et al. (2005), which was conducted on the mountain region of Rio de Janeiro state, and found positivity in $30.6 \%$ of young animals. Data obtained in the present study are particularly relevant because they were obtained from a non-mountainy region of the same state, confirming the high prevalence of this parasite in goats and calling attention for the importance of those animals as environmental contaminators (Robertson, 2009).

The finding of Giardia infection in only young animals could be explained by the fact that their immune system is still under development. They also shed a higher amount of cysts in feces, which facilitates the diagnosis (Xiao, 1994; Koudela and Vitovec, 1998). On the other hand, adult animals have better-developed immunity and shed smaller amounts of cysts in feces, which may not be detected on parasitological exams (Xiao, 1994; CastroHermida et al., 2005a).

Castro-Hermida et al. (2005a) noted a prevalence of up to $30 \%$ in adult goats, with the higher cyst shedding occurring in females during the first weeks after labor. However, this study used immunefluorescence as a diagnostic technique, which presents a higher sensitivity when compared to microscopy, and the samples were collected during the birth period. Thus, the methodological differences could have contributed for the discrepancies observed when comparing the results from this study with those described by Castro-Hermida et al. (2005a).

In addition to the differences inherent to the research methodology employed, several authors highlight that the differences in management and hygienic-sanitary conditions between the farms could affect the infection rate (Bomfim et al., 2005; Geurden et 
al., 2010). Among those, the type of material used to build the installations (wooden slats or masonry) was reported as an important risk factor for parasite transmission (Bomfim et al., 2005). Installations built with wooden slats floors favor fecal accumulation underneath them and the proliferation of flies, which can act as mechanical vectors of cysts (Doiz et al., 2000; Graczyk et al., 2005). Similarly, masonry floors favor humidity and fecal accumulation, maintaining the environmental contamination and favoring reinfection (Maddox-Hyttel et al., 2006).

When comparing the housing of young and adult animals in farm A, there was a correlation between wooden slats floors and positivity for Giardia. Adult animals raised semi-intensively in masonry floors did not show positivity for this parasite. However, the type of installation could not be considered the only risk factor, since animals from farm $B$ that were not positive for this parasite were also under intensive raising in wooden slats floor.

It is important to note that although hygienic-sanitary conditions in both farms were classified as unsatisfactory, the fecal material accumulated underneath the floor in farm $B$ was removed and deposited in dunghill. Conversely, the fecal material in farm $A$ remained underneath the floor, which contributes to the proliferation of flies and environmental contamination by cysts carried by rainwater. Moreover, several chicken were observed feeding from those fecal material, which can potentially favor the mechanical transmission of cysts (Majewska et al., 2009; Berrilli et al., 2012).

The presence of domestic animals in the same installations of goats was also reported as a risk factor for infection (Bomfim et al., 2005; Berrilli et al., 2012). In the present study, dogs and domestic birds were seen inside the young goat installations in farm $A$, which coincides with the only population found to be positive for Giardia cysts. This correlation becomes even more significant when one takes into consideration that Giardia intestinalis cysts were found in three canine fecal samples coming from the same farm. According to Traub et al. (2003), dogs could be reservoirs of this parasite or only act as mechanical transporters of cysts, contributing to environmental contamination and favoring goat infection, but molecular studies are still needed to confirm this hypothesis. Thus, we believe that the high rate of infection in young animals of farm $A$ is due to an association of factors. More specifically, the intensive raising of young animals in installations made of wooden slats floor, associated with fecal accumulation underneath it, and the presence of domestic animals inside the goat installations, are both related to the high rate of infection.

\section{References}

ALOISIO, F.; FILIPPINI, G.;ANTENUCCI, P.; LEPRI, E.; PEZZOTTI, G.; CACCIO, S.M.; POZIO, E. Severe weight loss in lambs infected with Giardia duodenalis assemblage B. Veterinary Parasitology, v.142, p.154-158, 2006.

BECHER, K.A.; FRASER, D.; THOMPSON, R.C.A. Giardia in Western Australian dairy calves. In: The Proceedings of the Eight International Coccidiosis Conference, Palm Cove, Cairns, Australia, July 9-13, p. 74-75, 2001.

BERRILLI, F.; D'ALFONSO, R.; GIANGASPERO, A.; MARANGI, M.; BRANDONISIO, O.; KABORE, Y.; GLE, C.; CIANFANELLI, C.; LAURO, R.; CAVE, D. Giardia duodenalis genotypes and Cryptosporidium species in humans and domestic animals in Côte dívoire: occurrence and evidence for environmental contamination. Transactions of the Royal Society of Tropical Medicine and Hygiene, v.106, p.191-195, 2012.
The finding of helminthes in animal feces only in farm A reinforces the importance of management and hygienic-sanitary conditions in goat infection. Several authors report frequent finding of helminthes in goats related to age, management, and sanitary conditions of livestock (Odoi et al., 2007; Khan et al., 2010; Guimarães et al., 2011; Ratanapob et al., 2012). We believe that the higher rates of adult infection in farm $A$ were related to semi-intensive raising of animals, associated with inadequate hygienic-sanitary conditions of installations, in addition to the fact that this farm did not use quarantine in goats recently introduced to the livestock. Those characteristics were also highlighted in studies made by Khan and colleagues (2010) in Pakistan and Guimarães and colleagues (2011) in Brazil. Moreover, all adult animals studied were female at reproductive age, which could have contributed to a greater rate of helminth infection, since pregnant and lactant females tend to eliminate a higher number of eggs in feces due to stress and immune status (Khan et al., 2010).

The helminth infection in young goats only found in farm A can be justified by the greater susceptibility of those animals to infection due to an immune system immaturity inherent to age (Khan et al., 2010), besides having poor hygienic-sanitary conditions in their housing.

Several authors reported high Eimeria infection rates in goats from Brazil similar to those observed in the present study, varying from $69.79 \%$ to $100 \%$ (Freitas et al., 2005; Hassum \& Menezes, 2005; Brito et al., 2009; Cavalcante et al., 2012; Coelho, Amarante \& Bresciani, 2012). This protozoa infection is very common in young and adult goats (Freitas et al., 2005; Cavalcante et al., 2012) and is associated with favorable environmental conditions, management practices and presence of infected adult animals in close contact with young animals (especially during lactation period) (Gauly et al., 2004; Hassum \& Menezes, 2005). All those features were observed in the studied population, contributing to the elevate percentage of infected animals reported.

The high infection rates of the studied population, together with the zoonotic potential of Giardia intestinalis, and the observation of possible risk factors for infection call attention for the need of more studies regarding epidemiology of Giardia in goats in Brazil. These studies could contribute to a better knowledge of the role of those animals in zoonotic transmission and to establish effective prophylactic measures to reduce environmental contamination and transmission risks.

BOMFIM, T.C.B.; HUBER, F.; GOMES, R.S.; ALVES, L.L. Natural infection by Giardia sp. and Cryptosporidium sp. in dairy goats, associated with possible risk factors of the studied properties. Veterinary Parasitology, v.134, p. 9-13, 2005.

BRITO, D.R.B.; SANTOS, A.C.G.; TEIXEIRA, W.C.; GUERRA, R.M.S.N.C. Parasitos gastrintestinais em caprinos e ovinos da microrregião do Alto Mearim e Grajaú, no Estado do Maranhão, Brasil. Ciência Animal Brasileira, v.10, n.3, p.967-974, 2009.

CASTRO-HERMIDA, J.A.; DELAFOSSE, A.; PORS, I.; ARESMAZÁS, E.; CHARTIER, C. Giardia duodenalis and Cryptosporidium parvum infections in adult goats and their implications for neonatal kids. The Veterinary Record, v.157, p.623-627, 2005a.

CASTRO-HERMIDA, J.A.; PORS, I.; POUPIN, B.; ARESMAZÁS, E.; CHARTIER, C. Prevalence of Giardia duodenalis and Cryptosporidium parvum in goat kids in western France. Small Ruminant Research, v.56, p. 259-264, 2005b. 
CASTRO-HERMIDA, J.A.; ALMEIDA, A.; GONZÁLEZ-WARLETA, M.; COSTA, J.M.C.; RUMBO-LORENZO, C.; MEZO, M. Occurrence of Cryptosporidium parvum and Giardia duodenalis in healthy adult domestic ruminants. Parasitology Research, v.101, p.1443-1448, 2007a.

CASTRO-HERMIDA, J.A.; GONZALEZ-WARLETA, M.; MEZO, $M$. Natural infection by Cryptosporidium parvum and Giardia duodenalis in sheep and goats in Galicia (NW Spain). Small Ruminant Research, v.72, p.96-100, 2007b.

CAVALCANTE, A.C.; TEIXEIRA, M.; MONTEIRO, J.P.; LOPES, C.W. Eimeria species in dairy goats in Brazil. Veterinary Parasitology, v.183, p. 356-358, 2012.

COELHO, W.M.D.; AMARANTE, A.F.T. and BRESCIANI, K.D.S. Occurrence of gastrointestinal parasites in goat kids. Revista Brasileira de Parasitologia Veterinária, v.21, n.1, p.65-67, 2012.

DÍAZ, V.; CAMPOS, M.; LOZANO, J.; MAÑAS, I.; GONZFILEZ, J. Aspects of animal giardiosis in Granada province (southern Spain). Veterinary Parasitology, v.64, p.171-176, 1996.

DOIZ, O.; CLAVEL, A.; MORALES, S.; VAREA, M.; CASTILLO, F.J.; RUBIO, C.; GÓMEZ-LUS, R. House fly (Musca domestica) as a transport vector of Giardia lamblia. Folia Parasitologica, v.47, p.330-331, 2000.

FENG, Y. and XIAO, L. Zoonotic Potential and Molecular Epidemiology of Giardia Species and Giardiasis. Clinical Microbiology Review, v.24, p.110-140, 2011.

FREITAS, F.L.; ALMEIDA, K.S.; NASCIMENTO, A.A.; MACHADO, C.R.; VESCHI, J.L.; MACHADO, R.Z. Species of the genus Eimeria Schneider, 1875 (Apicomplexa: Eimeriidae) in dairy goats maintained in intensive system in the São José do Rio Preto region, São Paulo State, Brazil. Revista Brasileira de Parasitologia Veterinária, v.14, n.1, p.7-10, 2005.

GAULY, M.; REEG, J.; BAUER, C.; ERHARDT, G. Influence of production systems in lambs on the Eimeria oocyst output and weight gain. Small Ruminant Research, v.55, p.159-167, 2004.

GUEURDEN, T.; THOMAS, P.; CASAERT, S.; VERCRUYSSE, J.; CLAEREBOUT, E. Prevalence and molecular characterization of Cryptosporidium and Giardia in lambs and goat kids in Belgium. Veterinary Parasitology, v.155, p.142-145, 2008.

GEURDEN, T.; VERCRUYSSE, J.; CLAEREBOUT, E. Is Giardia a significant pathogen in production animals? Experimental Parasitology, v.124, p. 98-106, 2010.

GRACZYK, T.K.; KNIGHT, R. AND TAMANG, L. Mechanical Transmission of Human Protozoan Parasites by Insects. Clininal Microbiology Review, v.18, p.128-132, 2005.

GUIMARÃES, A.S.; GOUVEIA, A.M.G.; CARMO, F.B.; GOUVEIA, G.C.; SILVA, M.X.; VIEIRA, L.S.; MOLENTO, M.B. Management practices to control gastrointestinal parasites in dairy and beef goats in Minas Gerais, Brazil. Veterinary Parasitology, v.176, p.265-269, 2011.

HASSUM, I.C. and MENEZES, R.C.A.A. Infecção natural por espécies do gênero Eimeria em pequenos ruminantes criados em dois municípios do Estado do Rio de Janeiro. Revista Brasileira de Parasitologia Veterinária, v.14, n. 3, p. 95-100, 2005.

HUBER, F.; SILVA, S.; BOMFIM, T.C.B.; TEIXEIRA, K.R.S.; BELLO, A.R. Genotypic characterization and phylogenetic analysis of Cryptosporidium sp. from domestic animals in Brazil. Veterinary Parasitology, v.150, p.65-74, 2007.
KHAN, M.N.; SAJID, M.S.; KHAN, M.K.; IQBAL, Z.; HUSSAIN, A. Gastrointestinal helminthiasis: prevalence and associated determinants in domestic ruminants of district Toba Tek Singh, Punjab, Pakistan. Parasitology Research, v.107, p.787-794, 2010.

KOUDELA, B. and VITOVEC, J. Experimental giardiasis in goat kids. Veterinary Parasitology, v.74, p. 9-18, 1998.

MADDOX-HYTTEL, C.; LANGKJAER, R.B.; ENEMARK, H.L.; VIGRE, H. Cryptosporidium and Giardia in different age groups of Danish cattle and pigs - Occurrence and management associated risk factors. Veterinary Parasitology, v.141, p.48-59, 2006.

MAJEWSKA, A.C.; GRACZYK, T.K.; SŁODKOWICZ-KOWALSKA, A.; TAMANG, L.; JĘDRZEJEWSKI, S.; ZDUNIAK, P.; SOLARCZYK, P.; NOWOSAD, A.; NOWOSAD, P. The role of free-ranging, captive, and domestic birds of Western Poland in environmental contamination with Cryptosporidium parvum oocysts and Giardia lamblia cysts. Parasitology Research, v.104, p.1093-1099, 2009.

ODOI, A.; GATHUMA, J.M.; GACHUIRI, C.K.; OMORE, A. Risk factors of gastrointestinal nematode parasite infections in small ruminants kept in smallholder mixed farms in Kenya. BMC Veterinary Research, v. 3, p. 6, 2007.

RATANAPOB, N.; ARUNVIPAS, P.; KASEMSUWAN, S.; PHIMPRAPHAI, W.; PANNEUM, S. Prevalence and risk factors for intestinal parasite infection in goats raised in Nakhon Pathom Province, Thailand. Tropical Animimal Health and Production, v. 44, p. 741-745, 2012.

ROBERTSON, L.J. Giardia and Cryptosporidium infections in sheep and goats: a review of the potential for transmission to humans via environmental contamination. Epidemiology and Infection, v.10, p.1-9, 2009.

RUIZ, A.; FORONDA, P.; GONZÁLEZ, J.F.; GUEDES, A.; ABREUACOSTA, N.; MOLINA, J.M.; VALLADARES, B. Occurrence and genotype characterization of Giardia duodenalis in goat kids from the Canary Islands, Spain. Veterinary Parasitology, v.154, p.137141, 2008.

SMITH, H.V.; CACCIÒ, S.M.; COOK, N.; NICHOLS, R.A.B.; TAIT, A. Cryptosporidium and Giardia as foodborne zoonoses. Veterinary Parasitology, v.149, p.29-40, 2007.

SPRONG, H.; CACCIÒ, S.M.; GIESSEN, J.W.B. Identification of Zoonotic Genotypes of Giardia duodenalis. Plos Neglected Tropical Diseases, v. 3, n.12, p. 558, 2009.

SWEENY, J.P.A.; RYAN, U.M.; ROBERTSON, I.D.; JACOBSON, C. Cryptosporidium and Giardia associated with reduced lamb carcase productivity. Veterinary Parasitology, v.182, p.127-139, 2011.

TRAUB, R.J.; ROBERTSON, I.D.; IRWIN, P.; MENCKE, N.; MONIS, P.; THOMPSON, R.C.A. Humans, dogs and parasitic zoonoses - unraveling the relationship in a remote endemic community in northeast India using molecular tools. Parasitology Research, v.90, p.S156-S157, 2003.

VAN DER GIESSEN, J.W.B.; VRIES, A.; ROOS, M.; WIELINGA, P.; KORTBEEK, L.M.; MANK, T.G. Genotyping of Giardia in Dutch patients and animals: A phylogenetic analysis of human and animal isolates. International Journal for Parasitology, v.36, p.849-858, 2006.

Xiao, L. Giardia infection in farm animals. Parasitology Today, v.10, n.11, p.436-438, 1994. 